\title{
Physician's Practice of Adverse Drug Reaction in Saudi Arabia
}

Yousef Ahmed Alomi* (iD, BSc. Pharm, MSc. Clin Pharm, BCPS, BCNSP, DiBA, CDE

Critical Care Clinical Pharmacists, TPN clinical pharmacist, Freelancer Business Planner, Content Editor and Data Analyst Riyadh, Riyadh, SAUDI ARABIA.

Nouf Hassan Alamoudi, PharmD,

Umm Al-Qura University, Makkah, SAUDI ARABIA.

Sabah Alanazi, B.D.S. Prince Sultan Medical Military City, Riyadh, SAUDI ARABIA. Abeer Hussin Almasoudi, BSc.Pharm Director, Administration of research and studies, Ministry of Health, Tabuk, SAUDI ARABIA.

\section{Correspondence:}

Dr. Yousef Ahmed Alomi, BSc. Pharm, MSc. Clin Pharm, BCPS, BCNSP, DiBA, CDE Critical Care Clinical Pharmacists, TPN clinical pharmacist, Freelancer Business Planner, Content Editor and Data Analyst P.O.BOX 100, Riyadh-11392, Riyadh, SAUDI ARABIA.

Phone no: +966504417712

E-mail:yalomi@gmail.com

Received: 11-10-2021;

Accepted: 13-12-2021

Copyright: () the author(s), publisher and licensee International Journal of Pharmacology and Clinical Sciences. This is an open-access article distributed under the terms of the Creative Commons Attribution Non-Commercial License, which permits unrestricted non-commercial use, distribution, and reproduction in any medium, provided the original work is properly cited.

This is an open access article distributed under the terms of the Creative Commons Attribution-NonCommercial-ShareAlike 4.0 License

Access this article online

\begin{tabular}{|c|c|}
\hline & www.ijpcs.net \\
\hline & DOI: \\
\hline
\end{tabular}

\section{ABSTRACT}

Objectives: To discover the healthcare providers (physicians and dentists) practice of the adverse drug reaction reporting system in Saudi Arabia. Methods: It was a crosssectional study with a self-administered electronic authenticated survey distributed to Saudi Arabia physicians and dentists. The survey contained of demographic data and rudiments of practicing the ADR reporting system, the number of ADR reported, the method of ADR reporting systems. Results: The total number of participants was 151. Of those, 111 (73.5\%) were physicians, while dentists were 39 (26.5\%). Of those 52 $(35.68 \%)$, only those who reported the ADR despite most responders $138(92.62 \%)$ thought the ADR reporting system was critical. The average scores of physicians practice ADR elements were 2.59. The physicians and dentists' responders had a high score of the agreement; ADR's essential tasks as a pharmacist. Conclusion: Over the past twenty years, more than theory studies and our study specified that ADR physicians' reporting was terrible. The switching accountability of ADR reporting from healthcare providers to the pharmacist is highly suggested.

Key words: Physician, Practice, Reporting, Adverse drug reaction, Saudi Arabia.

\section{INTRODUCTION}

The clinical pharmacy activity was well recognized in the Kingdom of Saudi Arabia for more than forty years. ${ }^{[1,2]}$ The drug information services included among clinical pharmacy services. $^{2}$ The drug information activities are well established, and adverse drug reaction reporting system comprised among those activities. ${ }^{[1,3]}$ The reporting of the ADR reporting system recognized altogether with drug information services. ${ }^{[4]}$ The ADR was recognized by drug information pharmacists and reported to the medication's registration department at the Ministry of Health and recently reported to the Saudi Food and Drug Authority (SFDA). ${ }^{[4]}$ The ADR reporting system encompassed a medication safety program in the past pharmacy strategic plan and the new plan with a new vision in $2030 . .^{[5-7]}$ The ADR reporting required from all healthcare professionals, including physicians, pharmacists and nurses. ${ }^{[8]}$ The knowledge and insight of healthcare professionals have an important role in ADR reporting practice, lack of knowledge and perception lead to ADR's under-reporting. As a result, variously reported the poor practice of ADR reporting system among physicians. Multiple inquiries found the insufficient practice of physician's knowledge, perception and practice the ADR reporting system among Saudi Arabia and some Arabic countries world-wide. [9-32] The reporting of ADR by physicians was found 5-34\% only from 15 studies world-wide. More than $80 \%$ did not get a training program

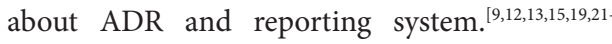
24,26,28-32] In Saudi Arabia, the number of studies showed to assess practice toward ADR reporting or pharmacovigilance between healthcare professionals, in Dammam city, 135 participants
(17 physicians of participants) designated $88.22 \%$ of the participants did not report ADRs.

In contrast, $57.7 \%$ have skilled ADRs during their professional. ${ }^{[14]}$ In Al-Khobar at King Fahd Hospital of the University, 331 participants (161 physicians of participants), a result specified to $88.8 \%$ had never reported, submitted, or identified any ADR reports. ${ }^{[13]}$ In Jeddah city, 337 hospital physicians contributed; a result showed that $57.6 \%$ of physicians had come across ADRs in practice, but only $21.7 \%$ reported these reactions. ${ }^{[12]}$ All previous studies did not debate the factors affecting the physician's practice of ADR with gender or age, qualifications and experiences. Also, most of the studies did usage authenticated methods of the cross-sectional survey. The current study with explore the physician's practice of the ADR reporting system and factoring the physician's practice in the Kingdom of Saudi Arabia.

\section{METHODS}

It is a descriptive analysis of a cross-sectional study of physicians' practice of the adverse drug reaction \& reporting system in Saudi Arabia. It was a self-administered electronic investigation for all physicians and dentists who worked in Saudi Arabia. All physicians' qualifications or types of specialties will be comprised in the study. All students will be omitted from the study. The survey comprised of two sections. The first part contained respondents' demographic data, comprising geographic location, gender, age, qualifications, specialties, the position held and working experiences. The second part had selected practice rudiments of the ADR system responsible for reporting $\mathrm{ADR}$, the number 
of $\mathrm{ADR}$ reporting and the methods of $\mathrm{ADR}$ reporting system from previous literature. [9,12,13,15,19,21-24,26,28-35] The 5-point Likert response scale system was employed with closed-ended questions. The sample calculated as crosssectional study according previous literature with the confidence level $95 \%$ with $\mathrm{z}$ score of 1.96 , margin of error (5-6.5\%), unlimited populations size, populations' percentage (50\%) and drop-out rate (10\%). As results, the sample size will equal to 251 to 432 with power of study of $80 \% .{ }^{[36-38]}$ The response rate required of calculated sample size at least 60-70 $\%$ and above. ${ }^{[38,39]}$ The survey was dispersed through social media whatsapp and telegram of physician's groups. Reminders message sent every 1-2 weeks. The survey was authenticated through the revision of expert reviewers and pilot testing. Besides, various tests of reliability McDonald's $\boldsymbol{\omega}$, Cronbach alpha, Guttmann's $\lambda 2$ and Guttmann's $\lambda \mathbf{6}$ had been completed with the study.

The survey analysis through monkey survey system, the statistical package of social sciences (SPSS), Jeffery's Amazing Statistics Pro (JASP) and Microsoft excel sheet version 16 with description and frequency analysis, good of fitness analysis, correlation analysis and inferential analysis of factors affects physician's knowledge of adverse drug reaction \& reporting system. The STROBE (Strengthening the reporting of observational studies in epidemiology statement: guidelines for reporting observational studies) showed the reporting of the current study. ${ }^{[40,41]}$

\section{RESULTS}

The total number of participants was 151 with response rate $(60.15 \%)$. Of those, 111 (73.5\%) were physicians, while 39 (26\%) were dentists. Most of them came from the central and north area 76 (50.68\%) and 27 (18\%), respectively, with statistically noteworthy among all regions $(p<0.05)$. The gender distribution was male 83 (54.97\%), and female was 68 (46.03\%) without any statistically momentous between them $(p>0.05)$. The most responders were in age (24$36)$ years $82(54.3 \%)$ and age (36-45) years 29 $(19.21 \%)$ with statistically noteworthy among them $(p<0.05)$. Many participant's experiences were residents $62(41.33 \%)$ and consultants 42 (28\%), while most of the responders held physicians or dental staff jobs 116 (77.33\%) with statistically significant among all type of qualification and position jobs $(p<0.05)$. Most of the responders had more than nine years' experience, 60 (40\%) and (1-3) years' experience $35(23.33 \%)$ with statistically significant among all period's levels $(p<0.05)$. Most physician participants were medical 19 $(12.67 \%)$ and the surgical field was 17 (9.33\%), while the dentist's specialisms were restorative dentistry $9(12.16 \%)$ from the total number of responders with statistically substantial among all subjects $(p<0.05)$ (Table 1 and 2$)$.

\section{The Practice of ADR Reporting}

In this study, only 52 (35.68\%) had stated ADR reactions before with important difference with non-reported before of ADR, or they do not know $(p<0.05)$. The average number of ADR was per patient. Despite that; the majority of responders thought ADR reporting is critical 138 (92.62\%) with a statistically important difference from other answers $(p<0.05)$ and responders had ADR reporting forms $60(40.27 \%)$ with a statistically significant alteration with outstanding answers $(p<0.05)$ (Table 3) The patients infrequently report ADR a few times per year or once a month, 57 (38.51\%) and 37 (25.\%), respectively. The first action of most of the responders exposed to severe ADR they contact with treating physician 67 (47.18\%), then direct the patients to the emergency room $65(45.77 \%)$ and document the ADR on patients profile 64 (45.07\%) (Table 4).

The average scores of rudiments of ADR reporting practice were (2.59) with a statistically significant difference among answers within each constituent $(p<0.05)$. The highest score element was ADR's prevailing policy and procedures (2.67) and implemented the ADR reporting system and quality management regulations (2.66). In contrast, the $\mathrm{ADR}$ reporting system's lowest score elements were the yearly plan of ADR (2.49) and the ADR reporting system (2.55). The average scores of the physician's perception of ADR responsibility were (4.10) with statistically significant differences within answers of each element $(p<0.05)$. The physicians stated that's doctors and pharmacists (4.46) and (4.5) respectively should be accountable for the ADR reporting system ( Table 5 and 6 ). The reliability test of McDonald's $\boldsymbol{\omega}$ (0.875), Cronbach alpha (0.808), Guttmann's $\lambda 2$ (0.870) and Guttmann's $\lambda 6(0.870)$.

There is not any statically significant relationship between factors (location, gender, age, qualifications, positions, years of experiences, physicians specialties and dentists specialisms) and all items for Adverse drug reaction (ADR) employment at the institution; physician's perception of reporting adverse drug reactions (to authorities) is the accountability, and some questions related of experiences of $\mathrm{ADR}$ reporting, $\mathrm{ADR}$ reporting practice for instance number of ADR pragmatic daily, number of a patient exposed to ADR daily and the importance of ADR reporting system $(p>0.05)$.
Factors Affecting the Practice of ADR Reporting

\section{Gender and Age}

There is a noteworthy difference between males and females in the practice of ADR with higher males than females in the mission of reporting ADR, the yearly plan of reporting $\mathrm{ADR}$, policy, and procedures of reporting $\mathrm{ADR}$, and writing capability ADR and writing capability ADR $(p<0.05)$ (Table 7$)$. There is no momentous difference among all age groups in all rudiments of ADR practice $(p>0.05)$.

\section{Qualifications and Specialty}

There is no substantial difference between practice elements and physician's qualifications (residents, specialist and consultant) except consultant more reporting of ADR than residents $(p<0.06)$. Also, the consultant is more alert of the availability of ADR's policy and procedures, yearly plan of ADR more than residents $(p<0.05)$. There is no significant difference among all type of physician

\begin{tabular}{|c|c|c|c|}
\hline Nationality & $\begin{array}{c}\text { Response } \\
\text { Count }\end{array}$ & $\begin{array}{c}\text { Response } \\
\text { Percent }\end{array}$ & P-Value \\
\hline Central area & 76 & $50.67 \%$ & \multirow[t]{5}{*}{$<0.05$} \\
\hline North area & 27 & $18.00 \%$ & \\
\hline South area & 12 & $8.00 \%$ & \\
\hline East area & 16 & $10.67 \%$ & \\
\hline West area & 19 & $12.67 \%$ & \\
\hline $\begin{array}{l}\text { Answered } \\
\text { question }\end{array}$ & 150 & & \\
\hline $\begin{array}{l}\text { Skipped } \\
\text { question }\end{array}$ & 1 & & \\
\hline Gender & $\begin{array}{c}\text { Response } \\
\text { Count }\end{array}$ & $\begin{array}{c}\text { Response } \\
\text { Percent }\end{array}$ & \\
\hline Male & 83 & $54.97 \%$ & \multirow[t]{2}{*}{$<0.05$} \\
\hline Female & 68 & $45.03 \%$ & \\
\hline $\begin{array}{l}\text { Answered } \\
\text { question }\end{array}$ & 151 & & \\
\hline $\begin{array}{l}\text { Skipped } \\
\text { question }\end{array}$ & 0 & & \\
\hline Age & $\begin{array}{c}\text { Response } \\
\text { Count }\end{array}$ & $\begin{array}{c}\text { Response } \\
\text { Percent }\end{array}$ & \\
\hline $24-35$ & 82 & $54.30 \%$ & $<0.05$ \\
\hline $36-45$ & 29 & $19.21 \%$ & \\
\hline $46-55$ & 16 & $10.60 \%$ & \\
\hline$>55$ & 24 & $15.89 \%$ & \\
\hline $\begin{array}{l}\text { Answered } \\
\text { question }\end{array}$ & 151 & & \\
\hline $\begin{array}{l}\text { Skipped } \\
\text { question }\end{array}$ & 0 & & \\
\hline
\end{tabular}




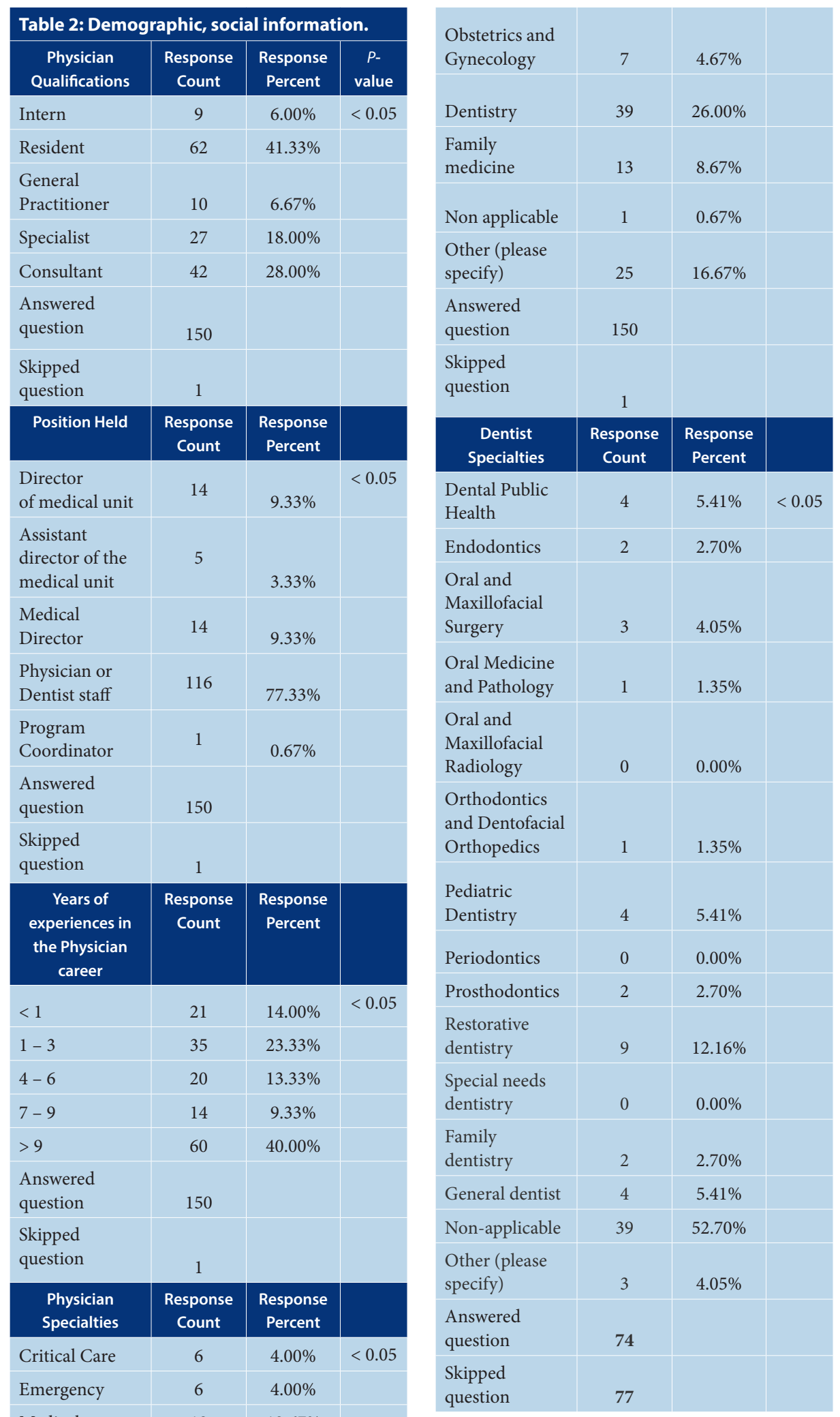

specialties (critical care, emergency, medical, surgical, pediatric, anesthesia, psychiatric, family medicine, obstetrics \& gynecology and dentistry) in all fundamentals of ADR practice $(p>0.05)$.
Table 3: Physicians' practice of reporting adverse drug reactions.

Have you ever reported any ADR?

\begin{tabular}{|l|c|c|c|}
\hline $\begin{array}{l}\text { Answer } \\
\text { Choices }\end{array}$ & \multicolumn{2}{|c|}{ Responses } & $P$-value \\
\hline Yes & 52 & $34.67 \%$ & $<0.05$ \\
\hline No & 88 & $58.67 \%$ & \\
\hline I do not know & 10 & $6.67 \%$ & \\
\hline Answered & 150 & & \\
\hline Skipped & 1 & & \\
\hline The number of patients visits daily. & \\
\hline Answer & Responses & \\
Choices & 105 & $70.95 \%$ & $<0.05$ \\
\hline $1-20$ & 30 & $20.27 \%$ & \\
\hline $21-40$ & 10 & $6.76 \%$ & \\
\hline $41-60$ & 2 & $1.35 \%$ & \\
\hline $61-80$ & 0 & $0.00 \%$ & \\
\hline $81-100$ & 1 & $0.68 \%$ & \\
\hline$>100$ & 148 & & \\
\hline Answered & 3 & \\
\hline Skipped & & \\
\hline
\end{tabular}

The number of ADR observed/suspected daily?

Answer Responses

Choices

\begin{tabular}{|l|l|l|l|}
\hline $1-5$ & 49 & $32.89 \%$ & $<0.05$ \\
\hline
\end{tabular}

6-10

11-15

$16-20$

21-25

26-30

$3 \quad 2.01 \%$

I do not know,

can not specify

$93 \quad 62.42 \%$

Answered

149

Skipped

2

Do you think that the reporting of ADR is important?

\begin{tabular}{|l|c|c|c|}
\hline $\begin{array}{l}\text { Answer } \\
\text { Choices }\end{array}$ & \multicolumn{2}{|c|}{ Responses } & \\
\hline Yes & 138 & $92.62 \%$ & $<0.05$ \\
\hline No & 6 & $4.03 \%$ & \\
\hline I do not know & 5 & $3.36 \%$ & \\
\hline Answered & $\mathbf{1 4 9}$ & & \\
\hline Skipped & $\mathbf{2}$ & & \\
\hline
\end{tabular}

How often do the patients report your ADRs of medications? 


\begin{tabular}{|l|c|c|}
\hline $\begin{array}{l}\text { Answer } \\
\text { Choices }\end{array}$ & \multicolumn{2}{|c|}{ Responses } \\
\hline 19 & $12.84 \%$ & $<0.05$ \\
\hline 37 & $25.00 \%$ & \\
\hline 57 & $38.51 \%$ & \\
\hline 35 & $23.65 \%$ & \\
\hline Answered & 148 & \\
\hline Skipped & 3 & \\
\hline $\begin{array}{l}\text { Do you have an ADR reporting form at your } \\
\text { institution? }\end{array}$ & Responses \\
\hline Answer \\
Choices
\end{tabular}

\section{Position and Experiences}

There is no noteworthy difference between physician positions (director of medical units, assistant director of the medical department, medical director and physician staff) and practice of adverse drug reaction $(p>0.05)$. There are no important differences among the majority of $\mathrm{ADE}$ practice basics between all types of experiences except for the lower experience (1-3 years) had more applied of the strategic plan of ADR, and the yearly plan of reporting ADR than high experience ( $>9$ years).

\section{DISCUSSION}

The medications' phases comprised of various steps that have encompassed procurement, prescribing, preparation, dispensing and monitoring. ${ }^{[42]}$ The last steps, monitoring medications, need several tools to influence the defined outcome of drug therapy, such as medication errors or adverse drug reaction prevention and documentation. ${ }^{[5,43]}$ The adverse drug reaction reporting chiefly was under-reporting by healthcare that is related to knowledge reasons or practice and insight reasons for healthcare providers, highlighting physicians. The current study reconnoitered the practice physicians of the ADR reporting system. The study had three quarters or responders were physicians, and one quarter were dentists. Many responders were young residents, physicians with various experiences, which imitate the high response of electronic surveys with fitting knowledge of using electronic devices. In the study, the results presented that only one-third of responders reported $\mathrm{ADR}$. At the same time, the majority

\section{Table 4: Processes of ADR reporting system. Answer Choices \\ Responses}

The Ministry of Health

(MOH).

63

$43.45 \%$

The Saudi food and drug

administration

79

$54.48 \%$

Drug company

$19.31 \%$

Pharmacy department

$68 \quad 46.90 \%$

Other (please specify)

7

$4.83 \%$

Answered

145

Skipped

6

How do you report the ADRs?

Answer Choices

Responses

I phone the drug company

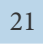

$14.58 \%$

I verbally inform the

representative of the drug

company on routine visits

10

$6.94 \%$

I mail the ADRs from via the internet

$17.36 \%$

I fill the adverse drug

reaction reporting form

91

$63.19 \%$

Other (please specify)

24

$16.67 \%$

Answered

Skipped

7

First actions that physicians perform when dealing with patients with severe adverse drug reactions (ADRs).

Answer Choices

Responses

Contact the physician 67 $47.18 \%$

Investigate if the $\mathrm{ADR}$ was known

$39 \quad 27.46 \%$

Report the ADR

$62 \quad 43.66 \%$

Ask the patient to contact the doctor

29

$20.42 \%$

Direct the patient to an emergency room

$45.77 \%$

Document the ADR in the patient's file

$45.07 \%$

Recommend the patient to discontinue the drug with no further action 24

$16.90 \%$

Answered

Skipped 9

did not even send any ADR during their practice period despite the ADR reporting system's vital opinions, which reliable with previous

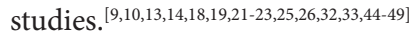

Further, it might be the ADR not readily obtainable at the front medical disk or nursing station at the wards or clinics. The ADR reporting system was incompetently implemented with most practice elements related to inadequate knowledge of physicians of the practice or not practice or seldom doing the exercise of ADR reporting system and contained with another study. ${ }^{[22,25,45]}$ Few physicians familiar with ADR policy \& procedures implementation and might practice it like aforementioned studies. ${ }^{[46]}$

The inadequacy of education and training or inadequate practice at their organization facilities contributes like previous studies. $[22,26,29,30,48]$ The physicians thought the accountability of ADR was supposed to be physicians or pharmacists and less likely with nurses or pharmacy technicians because of more knowledge than physicians of pharmacovigilance system. ${ }^{[10,13,23,27,31,49]}$ To progress practice physicians to ADR reporting system, we propose transferring the full time activity to the pharmacist and may aid the physicians and facilitates the ADR reporting system with collaboration with physicians and other healthcare providers. It wants fulltime employees (FTE) to implement the ADR reporting system and displays it daily. Because the pharmacist more familiar with the design and required quality management standards to follow up and document ADR. Also, the physicians do not need wide-ranging courses and extra work of follow-up by pharmacist or quality management services for ADR reporting system that will protect time and effectors. Besides, the patients hardly report ADR reporting to physicians, and it will not occur except for patients to do the job of ADR reporting. The pharmacist can contact patients to text ADR and prevent any ADR sequence risk for patients. The physicians will deal with severe ADR unsuitable way, and that had been from trained physicians or dentists. As a result, the physicians can call the pharmacist to help him in emergency ADR and solve the glitches, and document all sever ADR related issues.

The ADR reporting practice will not be pretentious by several variables, comprising location, age, qualifications, positions, years of experience, physicians' specialties and dentists' specialties, which varies from the earlier study ${ }^{[30]}$ However, the male were more knowledgeable and perception than female about adverse drug reaction reporting. The difference of the preceding research might be related to a well-established system of ADR and occasionally education and training about the ADR reporting system. ${ }^{[30]}$ There was not any association between them. Some factors found might make some difference in ADR reporting, for example, gender without clear aims. Also, the consultant or higher qualifications or 


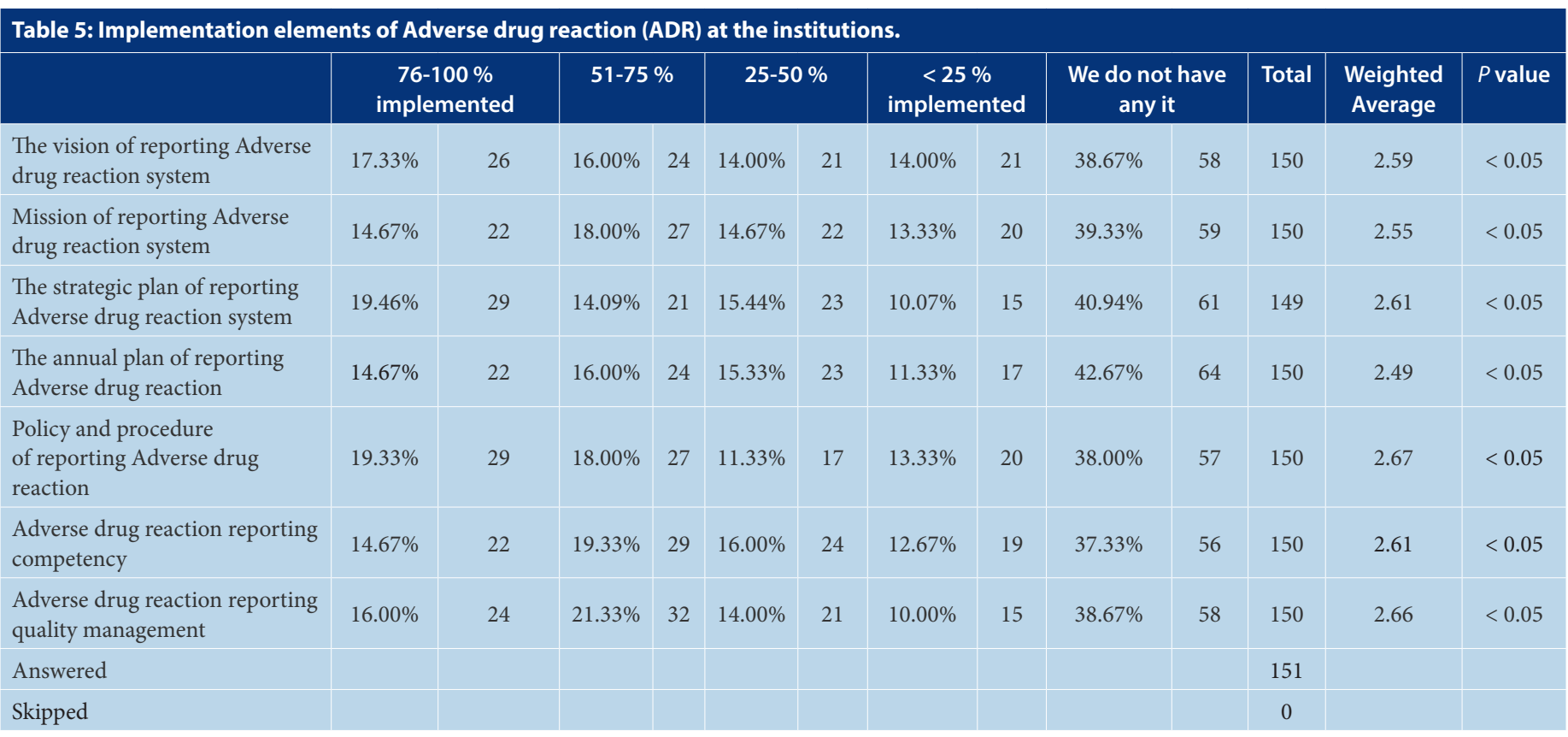

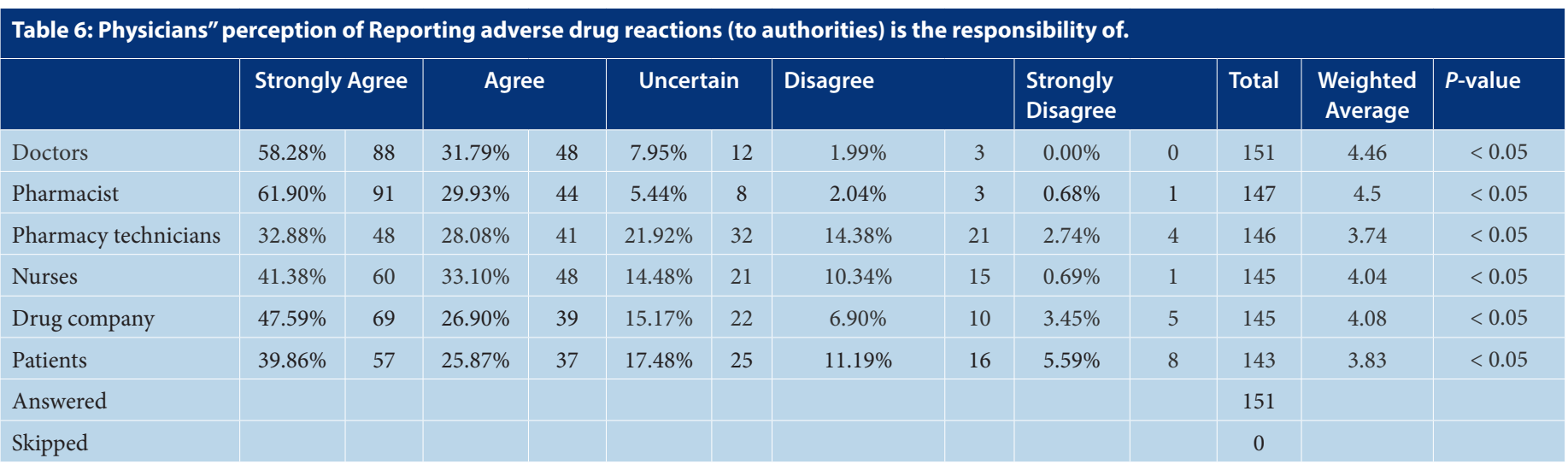

\begin{tabular}{|c|c|c|c|c|c|c|c|c|c|c|c|c|c|c|c|}
\hline \multirow{2}{*}{$\begin{array}{l}\text { Mission of reporting } \\
\text { Adverse drug } \\
\text { reaction system }\end{array}$} & \multirow{2}{*}{$\begin{array}{l}\text { factors } \\
\text { Male }\end{array}$} & \multicolumn{2}{|c|}{$\begin{array}{c}76-100 \% \\
\text { implemented }\end{array}$} & \multicolumn{2}{|c|}{$51-75 \%$} & \multicolumn{2}{|c|}{$25-50 \%$} & \multicolumn{2}{|c|}{$\begin{array}{c}<25 \% \\
\text { implemented }\end{array}$} & \multicolumn{2}{|c|}{$\begin{array}{l}\text { We do not } \\
\text { have any it }\end{array}$} & \multicolumn{2}{|c|}{ Total } & \multirow{2}{*}{$\begin{array}{c}\text { Weighted } \\
\text { Average } \\
2.81\end{array}$} & \multirow{2}{*}{$\begin{array}{c}\boldsymbol{p} \\
\text { value } \\
<0.05\end{array}$} \\
\hline & & $20.48 \%{ }^{*}$ & 17 & $19.28 \%$ & 16 & $13.25 \%$ & 11 & $14.46 \%$ & 12 & $32.53 \%$ & 27 & $54.97 \%$ & 83 & & \\
\hline & Female & $7.46 \%^{\star}$ & 5 & $16.42 \%$ & 11 & $16.42 \%$ & 11 & $11.94 \%$ & 8 & $47.76 \%$ & 32 & $44.37 \%$ & 67 & 2.24 & $<0.05$ \\
\hline \multirow{2}{*}{$\begin{array}{l}\text { The annual plan } \\
\text { of reporting Adverse } \\
\text { drug reaction }\end{array}$} & Male & $20.48 \%^{*}$ & 17 & $19.28 \%$ & 16 & $13.25 \%$ & 11 & $10.84 \%$ & 9 & $36.14 \%$ & 30 & $54.97 \%$ & 83 & 2.77 & $<0.05$ \\
\hline & Female & $7.46 \%^{\star}$ & 5 & $11.94 \%$ & 8 & $17.91 \%$ & 12 & $11.94 \%$ & 8 & $50.75 \%$ & 34 & $44.37 \%$ & 67 & 2.13 & $<0.05$ \\
\hline \multirow{2}{*}{$\begin{array}{l}\text { Policy and procedure } \\
\text { of reporting Adverse } \\
\text { drug reaction }\end{array}$} & Male & $25.30 \%^{*}$ & 21 & $24.10 \%^{*}$ & 20 & $10.84 \%$ & 9 & $13.25 \%$ & 11 & $26.51 \%^{*}$ & 22 & $54.97 \%$ & 83 & 3.08 & $<0.05$ \\
\hline & Female & $11.94 \%^{*}$ & 8 & $10.45 \%^{*}$ & 7 & $11.94 \%$ & 8 & $13.43 \%$ & 9 & $52.24 \%^{*}$ & 35 & $44.37 \%$ & 67 & 2.16 & $<0.05$ \\
\hline \multirow{2}{*}{$\begin{array}{l}\text { Adverse drug } \\
\text { reaction reporting } \\
\text { competency }\end{array}$} & Male & $20.73 \%^{*}$ & 17 & $20.73 \%$ & 17 & $17.07 \%$ & 14 & $13.41 \%$ & 11 & $28.05 \%^{*}$ & 23 & $54.30 \%$ & 82 & 2.93 & $<0.05$ \\
\hline & Female & $7.35 \% *$ & 5 & $17.65 \%$ & 12 & $14.71 \%$ & 10 & $11.76 \%$ & 8 & $48.53 \%^{*}$ & 33 & $45.03 \%$ & 68 & 2.24 & $<0.05$ \\
\hline
\end{tabular}


many years of experience had more practice with some ADR reporting system which look like former studies). ${ }^{[9,50]}$ Other factors will not make any difference, for instance, age levels, physician's qualifications, or positions.

\section{Limitations}

The current study was showed in detail about ADR's practice and related issues, with a authorized survey from expert reviewers and various reliability test applications. The study also deliberated the factors that exaggerated physician's or dentists' practice in the ADR reporting system. However, the study had various boundaries, including the sample sized not optimal, which could not signify the total number of participants, either physicians or dentists. The study does not have an equal number of type participants, physicians and dentists; most responders were physicians, making it stimulating to liken physicians and dentists. Many responders were young with fewer experiences and qualifications that is main the findings express that young category of physicians and dentists. The future study with a high number of samples and an equal number of physicians and dentists or choose one of them, and an equal number of qualifications and experiences are documented to explain all study limitations.

\section{CONCLUSION}

This study was steered among physicians and dentists about the physician's practice of the ADR reporting system. The self-administered questionnaire was authenticated through various methods and multiple biostatistics reliability tests. The outcomes showed that the ADR system was incompetently implemented and poor reporting of ADR look like the previous studies. That is related to insufficient knowledge and missing of ADR education and training. There were various challenges of physicians practicing the ADR system. The pharmacist should be more conversant and practice than all healthcare professionals. It will improve $\mathrm{ADR}$ reporting system by transferring complete accountability from all healthcare providers to pharmacists through full documentation of ADR and following up all ADR reporting matters in Saudi Arabia.

\section{ACKNOWLEDGEMENT}

None.

\section{CONFLICT OF INTEREST}

The authors declare that there is no conflict of interest.
Funding

None

\section{Consent for Publications}

Informed consent was obtained from all the participants

\section{Ethical Approval}

This research is exempted from research and ethical committee or an institutional review board (IRB) approval.

https://www.hhs.gov/ohrp/regulations-andpolicy/decision-charts-2018/index.html

\section{ABBREVIATIONS}

MOH: Ministry of Health; KSA: Kingdom of Saudi Arabia; ADR: Adverse Drug Reactions; SFDA: Saudi Food and Drug Authority; SPSS: Statistical Package of Social Science; JASP: Jeffery's Amazing Statistics.

\section{ORCID ID}

Yousef Ahmed Alomi org/0000-0003-1381-628X

\section{REFERENCES}

1. Alomi YA, Alghamdi SJ, Alattyh RA. History and Strategies of Drug Information Services at Ministry of Health in Saudi Arabia. Pharmacol Toxicol Biomed Reports. 2019;5(1):1-3

2. Alomi YA. National Drug Information Center Pro at Ministry of Health in Saudi Arabia. Adv Pharmacoepidemiol Drug Saf. 2016;05(01):1-2.

3. Alomi YA, Aldosary BA. Cost Analysis of Activities for Network Drug Information Centers at the Ministry of Health Hospitals in Saudi Arabia. Int J Pharm Heal Sci. 2019;2(1):45-51.

4. Alomi YA, Alghamdi SJ, Alattyh RA. National Adverse Drug Reaction Reporting System at the Ministry of Health, Saudi Arabia. Pharmacol Toxicol Biomed Reports. 2019;4(3):21-3.

5. Alomi YA. National Medication Safety Pro at Ministry of Health in Saudi Arabia. J Pharmacovigil. 2015;3(5):e145.

6. Alomi YA, Alghamdi SJ, Alattyh RA. Strategic Plan of General Administration of Pharmaceutical Care at Ministry of Health in Saudi Arabia 2012-2022. J Pharm Pharm Scien. 2015;1(13):1-8.

7. Alomi YA, Alghamdi SJ, Alattyh RA, Elshenawy RA. The Evaluation of Pharmacy Strategic Plan in Past 2013-2016 and Forecasting of New Vision 2030 at Ministry of Health in Saudi Arabia. J Pharm Pract Community Med. 2018;4(2):93-101.

8. Saudi Central Board for Accreditation of Healthcare Institutions. National Hospital Standards. Third edit. Saudi Central Board for Accreditation of Healthcare Institutions. 2016

9. Kamal NN, Kamel EG, Mahfouz EM. Adverse Drug Reactions Reporting, Knowledge, Attitude and Practice of Physicians towards it in El Minia University Hospitals. Int Public Heal Forum. 2014; 1(4):13-7.

10. Abdel-Latif MMM, Abdel-Wahab BA. Knowledge and awareness of adverse drug reactions and pharmacovigilance practices among healthcare professionals in Al-Madinah Al-Munawwarah, Kingdom of Saudi Arabia. Saudi Pharm J. 2015;23(2):154-61.

11. Al-Arifi MN, Mayet AY, Wajid S, Al-Saadi M, Babelghaith AEMISD, Al Ayoubi FZ. Knowledge, attitude and perception of physicians towards adverse drug reaction reporting at king Khalid university hospital, Riyadh, Saudi Arabia. Trop J Pharm Res. 2015;14(5):907-11.

12. Bakhsh T, Al-Ghamdi M, Bawazir S, Omer $T$ Qureshi N. Assessment of Hospital Physicians' Knowledge, Awareness, Attitude and Practice of Reporting Adverse Drug Reactions in Jeddah, Saudi Arabia. Br J Med Med Res. 2016;10;16(1):116.

13. Almandil NB. Healthcare professionals' awareness and knowledge of adverse drug reactions and pharmacovigilance. Saudi Med J. 2016;37(12):1350-5.

14. Ali MD, Hassan YA, Ahmad A, Alaqel O, Al-Harbi $\mathrm{H}$, Al-Suhaimi NM. Knowledge, Practice and Attitudes toward Pharmacovigilance and Adverse Drug Reactions Reporting Process among Health Care Providers in Dammam, Saudi Arabia. Curr Drug Saf. 2017;13(1):21-5.

15. Alsaleh FM, Lemay J, AIDhafeeri RR, AIAjmi S, Abahussain EA, Bayoud T. Adverse drug reaction reporting among physicians working in private and government hospitals in Kuwait. Saudi Pharm J. 2017;25(8):1184-93.

16. Moinuddin K, Ali S, Al-Aqqad AQ, Salem SO, Al-Dossari MA, Ananzeh AM, et al. Knowledge and attitude of health-care professionals toward adverse drug reactions reporting at King Saud Medical City. J Pharm Bioallied Sci. 2018;10(1):2934.

17. AlShammari TM, Almoslem MJ. Knowledge, attitudes \& practices of healthcare professionals in hospitals towards the reporting of adverse drug reactions in Saudi Arabia: A multi-centre cross sectional study. Saudi Pharm J. 2018;26(7):925-31.

18. Ashraf TN, Alromaih AA, Aldahash AA, Almuhesseny AA, Alotaibi SH, Saad Al, et al. Knowledge, Attitude and Practice of Pharmacovigilance in Healthcare Professionals and Medical Students in Majmaah, Saudi Arabia Care Centre. Int J Med Res Heal Sci. 2018;7(4):101-7.

19. Shroukh WA, Shakhatreh FM, Yasein NA, Sharkas GF. A survey on the knowledge attitudes and practices of physicians towards pharmacovigilance in Jordanian health centres. Int Health. 2018;10(5):363-70.

20. AlKablaniTS, AIShamsi HS, Almutairi AG. Reporting on Adverse Drug Reactions: Knowledge, Attitudes and Practice among Physicians Working at Healthcare Institutions in Al-Buraimi GovernorateOman. Glob J Health Sci. 2018;10(8):107.

21. Upadhyaya HB, Vora MB, Nagar JG, Patel PB. Knowledge, attitude and practices toward pharmacovigilance and adverse drug reactions in postgraduate students of Tertiary Care Hospital in Gujarat. J Adv Pharm Technol Res. 2015;6(1):2934

22. Nisa ZU, Zafar A Sher F Assessment of knowledge, attitude and practice of adverse drug reaction reporting among healthcare professionals in secondary and tertiary hospitals in the capital of Pakistan. Saudi Pharm J. 2018;26(4):453-61.

23. Lemay J, Alsaleh FM, Al-Buresli L, Al-Mutairi M Abahussain EA, Bayoud T. Reporting of Adverse Drug Reactions in Primary Care Settings in Kuwait: A Comparative Study of Physicians and Pharmacists. Med Princ Pract. 2018;27(1):30-8.

24. Kassa Alemu B, Biru TT. Health care professionals' knowledge, attitude and practice towards adverse drug reaction reporting and associated factors at selected public hospitals in northeast Ethiopia: A cross-sectional study. Biomed Res Int. 2019.

25. Nahar N, Khan MTH, Banu LA, Khan MI, Hossain AM. Perceptions of Medical Practitioner Regarding Adverse Drug Reactions Reporting and Pharmacovigilance. J Shaheed Suhrawardy Med Coll. 2017;6(1):18-22.

26. Haines HM, Meyer JC, Summers RS, Godman $\mathrm{BB}$. Knowledge, attitudes and practices of health 
care professionals towards adverse drug reaction reporting in public sector primary health care facilities in a South African district. Eur J Clin Pharmacol. 2020;76(7):991-1001.

27. Binu KB, Sarika R, Denna SJ, Merin AA, Riya JHD, et al. Assessment of Knowledge, Attitude and Perception of Healthcare Professionals towards Adverse Drug Reactions Reporting : A Questionnaire Based Survey. Saudi J Med Pharm Sci. 2017;03(3A):124-32.

28. Adisa R, Omitogun TI. Awareness, knowledge, attitude and practice of adverse drug reaction reporting among health workers and patients in selected primary healthcare centers in Ibadan, southwestern Nigeria. BMC Health Serv Res. 2019;19(1).

29. Güner MD, Ekmekci PE. Healthcare professionals' pharmacovigilance knowledge and adverse drug reaction reporting behavior and factors determining the reporting rates. J Drug Assess. 2019;8(1):13-20

30. Nadew SS, Michael Beyene KG, Beza SW. Adverse drug reaction reporting practice and associated factors among medical doctors in government hospitals in Addis Ababa, Ethiopia. PLoS One. 2020;15(1).

31. MM T, BC T. Assessment of Knowledge, Attitude and Practices of Adverse Drug Reaction Reporting among Doctors and Pharmacists in Primary Healthcare. Adv Pharmacoepidemiol Drug Saf. 2016;5(4):1-6.

32. Gidey K, Seifu M, Hailu BY, Asgedom SW, Niriayo $Y L$. Healthcare professional's knowledge, attitude and practice of adverse drug reactions reporting in Ethiopia: A cross-sectional study. BMJ Open. 2020;10(2).

33. Paveliu MS, Bengea-Luculescu S, Toma M, Paveliu SF. Perception on adverse drug reaction reporting by physicians working in southern romania.
Maedica. 2013;8(1):17-25.

34. Kamtane RA, Jayawardhani V. Knowledge, attitude and perception of physicians towards adverse drug reaction (ADR) reporting: A pharmacoepidemiological study. Int J Pharm Pharm Sci. 2012;4(Suppl 4):698-704.

35. Fouad F, Doughan A, Alomi YA, Iflaifel $\mathrm{MH}$. Pharmacist's Practice of Reporting of Adverse Drug Reactions. Int J Pharmacol Clin Sci. 2019;8(1):86-93.

36. Charan J, Biswas T. How to calculate sample size for different study designs in medical research? Vol. 35, Indian Journal of Psychological Medicine. 2013;35(2):121-6.

37. Pourhoseingholi MA, Vahedi $M$, Rahimzadeh M. Sample size calculation in medical studies. Gastroenterol Hepatol from Bed to Bench. 2013;6(1):14-7.

38. Ezhumalai G. How big a sample do I need requir. Ann SBV. 2017;6(1):39-41.

39. Johnson TP, Wislar JS. Response rates and nonresponse errors in surveys. JAMA. 2012;307:1805- 6.

40. Erik EV, Douglas GA, Matthias E, Stuart JP, Peter C, Gøtzsche JPV. The Strengthening the Reporting of Observational Studies in Epidemiology (STROBE) Statement: Guidelines for Reporting Observational Studies. PLoS Med. 2007;4(10):1623-7.

41. Von Elm E, Altman DG, Egger M, Pocock SJ, Gøtzsche PC, Vandenbroucke JP. The Strengthening the Reporting of Observational Studies in Epidemiology (STROBE) statement: Guidelines for reporting observational studies [Internet]. 2007;370. www.thelancet.com. Available from: www.plosmedicine.org

42. Medication management system. Saudi Center Board for Accreditation for Healthcare Institutions
(CBAHI). 2016.

43. AHSP. ASHP statement on pharmaceutical care. Am J Hosp Pharm. 1993;50(50):1720-3.

44. Oshikoya KA, Awobusuyi JO. Perceptions of doctors to adverse drug reaction reporting in a teaching hospital in Lagos, Nigeria. BMC Clin Pharmacol. 2009;9(4):1-8.

45. Hussain R, Hassali MA, UrRehmanA, Muneswarao J, Hashmi F. Physicians' understanding and practices of pharmacovigilance: Qualitative experience from a lower middle-income country. Int J Environ Res Public Health. 2020;17(7):1-15.

46. Pimpalkhute SA, Jaiswal KM, Sontakke SD, Bajait CS, Gaikwad A. Evaluation of awareness about pharmacovigilance and adverse drug reaction monitoring in resident doctors of a tertiary care teaching hospital. Indian J Med Sci. 2012:66(34):55-61.

47. Saurabh MK, Karnani RK. An evaluation of knowledge, attitude and perception about adverse drug reactions and pharmacovigilance among intern doctors at a teaching hospital of Rajasthan Natl J Physiol Pharm Pharmacol. 2016;6(2):111-5.

48. Catic T, Begović B. The attitudes of pharmacists and physicians in Bosnia and Herzegovina towards adverse drug reaction reporting. J Heal Sci. 2016;6(1):37-45.

49. Shamim S, Sharib SM, Malhi SM, Muntaha S ul, Raza H, Ata S, et al. Adverse drug reactions (ADRS) reporting: Awareness and reasons of under-reporting among health care professionals, a challenge for pharmacists. Springerplus. 2016;5(1):1778

50. Bakhsh T, Al-Ghamdi M, Bawazir S, Al-Raddadi R, Qureshi N. Physicians Sociodemographics and Knowledge, Awareness, Attitude and Practice towards Reporting Adverse Drug Reactions: An Association Study in Jeddah City, Saudi Arabia. Br J Pharm Res. 2016;12(3):1-15 